\title{
Effect of curing temperature and time on the mechanical properties of hydroxyapatite/calcined kaolin
}

\author{
Ratchawoot Sutthi ${ }^{\mathrm{a}}$, Nisanath Kaewwinud ${ }^{\mathrm{b}}$, Prinya Chindaprasirt ${ }^{\mathrm{c}}$, Yoshiharu Mutoh ${ }^{\mathrm{d}}$, \\ Teerawat Laonapakul ${ }^{\mathrm{a}, *}$ \\ a Department of Industrial Engineering, Faculty of Engineering, Khon Kaen University, \\ Khon Kaen 40002 Thailand \\ b Engineering and Technology Management Program, Faculty of Industrial Technology, \\ Surindra Rajabhat University, Surin 32000 Thailand \\ c Sustainable Infrastructure Research and Development Centre, Department of Civil Engineering, \\ Faculty of Engineering, Khon Kaen University, Khon Kaen 40002 Thailand; and Academy of Science, \\ The Royal Society of Thailand, Dusit, Bangkok 10300 Thailand \\ d (Professor Emeritus) Nagaoka University of Technology, Nagaoka, Niigata 940-2188 Japan
}

*Corresponding author, e-mail: teerla@kku.ac.th

Received 15 Jul 2018

Accepted 12 Dec 2018

\begin{abstract}
In the current study, improvement of HAp/Calcined kaolin (CK) strength as a function of its curing regime was studied. The influence of curing temperature and time on the compressive strength of hydroxyapatite combined with calcined kaolin (HAp/CK) samples was investigated using statistical analysis. Curing temperatures were ranged $40,60,80^{\circ} \mathrm{C}$ and curing times were $2,7,14,21,28$ days, respectively. Prolonged curing time and increased curing temperature improved the compressive strength of the samples. The curing time and temperature significantly affected the compressive strength of HAp/CK samples, while there was no interaction between curing time and curing temperature. The highest compressive strength, $37.8 \mathrm{MPa}$, was realized by curing the sample at $80^{\circ} \mathrm{C}$ for 28 days. The optimal process was curing $\mathrm{HAp} / \mathrm{CK}$ at $60^{\circ} \mathrm{C}$ for 14 days to achieve a high compressive strength.
\end{abstract}

KEYWORDS: compressive strength, bone substitute materials, calcium phosphate bioceramics, geopolymer

\section{INTRODUCTION}

Nowadays, a number of bone substitute materials including metals, polymers, and ceramics have been developed as alternatives for bone repair, augmentation or substitution ${ }^{1}$. The aim of development of bone substitutes is into create materials that have mechanical and chemical properties closest to those of human bone. Due to their bioactivity and biocompatibility, $\mathrm{Ca}_{3}\left(\mathrm{PO}_{4}\right)_{2}$ bioceramics, such as hydroxyapatite (HAp) and $\beta$-tricalcium phosphate $(\beta-\mathrm{TCP})$, have been widely employed for bone repairs, fixing $d$ efects o $r$ fi lling vo ids. Th ese are available in various forms, such as powders, porous scaffolds, blocks, or beads ${ }^{2-4}$. Unfortunately, low strength, fracture toughness and brittleness of HAp and $\beta$-TCP have limited its application to just bone repairs or low weight bearing monolithic implants. Geopolymer is a three-dimensional aluminosilicate polymeric structure, which consists of Si-O-Al bonds a chemical reaction between $\mathrm{SiO}_{2}$ and $\mathrm{Al}_{2} \mathrm{O}_{3}$ under highly alkali conditions ${ }^{5}$. The materials that are currently attracting interest as bone substitutes or fillers are geopolymers and synthetic aluminosilicates $^{6-9}$. Calcined kaolin (CK) is an aluminosilicate material that can be used as a starting material to obtain high strength geopolymers ${ }^{10-13}$. To produce biomaterials, clean source materials with minimum contamination are needed. The white coloured CK seems to be the best source material for this purpose.

On a review of literature, the property that is most often used to characterize the mechanical behaviour of bone substitute is their compressive strength. The compressive strength of porous human bone varies between 2 and $42 \mathrm{MPa}$ for cancellous bone and between 100 and $230 \mathrm{MPa}$ for cortical bone $^{14,15}$. From previous research, mixtures of HAp with CK were investigated for their strengths and apatite formation ${ }^{16}$. The maximum compressive strength obtained from an HAp:CK mix at a ratio of 
1:3 was $32.9 \mathrm{MPa}$ when cured at $60^{\circ} \mathrm{C}$ for $48 \mathrm{~h}$. This HAp:CK material exhibited good bioactivity after immersion in simulated body fluids for 28 days. However, varying curing time and temperature may have substantial effects on the ultimate properties of the final $\mathrm{p}$ roduct. This s tudy i nvestigated the improved strength of HAp mixed with CK in terms of the curing regime used. The effect of curing time and temperature on the compressive strength of the HAp:CK final product was also investigated. Statistical analysis was done to determine the level of influence of each factor. SPSS was used assuming a normal distribution. Two-way ANOVA and Duncan's multiple range tests were used in the statistical analysis.

\section{MATERIALS AND METHODS}

\section{Preparation of starting materials}

Hydroxyapatite (HAp) and calcined kaolin (CK) powders were used as the raw materials in this study. For the preparation of HAp powder, calcium carbonate $\left(\mathrm{CaCO}_{3}\right)$ produced from golden apple snail shell (calcined at $600^{\circ} \mathrm{C}$ for $3 \mathrm{~h}^{17}$ ) and dicalcium phosphate dihydrate $\left(\mathrm{CaHPO}_{4} \cdot 2 \mathrm{H}_{2} \mathrm{O}\right.$, DCPD, Sigma Aldrich) were mechanochemically mixed at a theoretical stoichiometric $\mathrm{Ca} / \mathrm{P}$ molar ratio (1.67) to produce HAp. This was done in a ball mill for $24 \mathrm{~h}$. Then the material was heat-treated at a temperature of $1100^{\circ} \mathrm{C}$ for $1 \mathrm{~h}$. The crystalline phase of prepared HAp powder was identified using an Xray diffraction equipment (XRD, Bruker D8). The $\mathrm{XRD}$ analysis was carried out with $\mathrm{CuK} \alpha$ radiation operating at a scanning rate of $2.4^{\circ} \mathrm{C} 2 \theta / \mathrm{min}$ in $0.02{ }^{\circ} \mathrm{C} 2 \theta$ increment.

Calcined kaolin (CK) was prepared by calcination of metakaolin at a temperature of $600{ }^{\circ} \mathrm{C}$ in an electric furnace. The metakaolin used as the starting material was obtained from the eastern region of Thailand. Chemical composition of CK was determined using an X-ray fluorescence (WDXRF, AXios $\mathrm{mAX}) . \mathrm{NaOH}(10 \mathrm{M})$ and sodium silicate $\left(15 \% \mathrm{Na}_{2} \mathrm{O}, 33 \% \mathrm{SiO}_{2}\right.$ and $\left.52 \% \mathrm{H}_{2} \mathrm{O}\right)$ with a mass ratio of 1.0 were used as a liquid activated binder for the HAp and CK powders.

\section{Material preparation and evaluation}

Hydroxyapatite (HAp) and calcined kaolin (CK) powders with an HAp:CK mass ratio of $1: 3$ (HAp/CK 25) was selected to study the influence of curing time and temperature on the compressive strength of the synthesized samples. This ratio was selected due to the high compressive strength and good bioactivity of samples prepared at this ratio ${ }^{16}$. The HAp/CK 25 powders were mechanically mixed with an activated binder solution using a planetary mixer for $5 \mathrm{~min}$. The resulting sample paste was then rapidly poured into a $25 \times 25 \times 25 \mathrm{~mm}^{3}$ acyclic cube mould, and then mechanically vibrated for $10 \mathrm{~s}$ to remove entrapped air. Samples were carefully wrapped with a plastic film to prevent moisture loss. The cast samples were then separately cured in electric ovens.

In this study, two factors were varied, curing temperature and time, to investigate their effect on the compressive strength of HAp/CK 25. Three curing temperatures, 40,60 , and $80^{\circ} \mathrm{C}$, and five curing times, $2,7,14,21$, and 28 days, were evaluated. The samples cured for less than 28 days were removed from their moulds, wrapped in a plastic film and then stored at $23^{\circ} \mathrm{C}$ until the 28 days. It has been reported that the temperature curing of 2 days produced geopolymer with a sufficiently high strength ${ }^{18-20}$. Hence the strength test at 2 days was performed in this experiment. Compressive strength tests were conducted on three cubed samples per each condition and the results were reported as the average values according to ASTM C109 ${ }^{21}$. The statistical methods were employed to analyse the level of each factor using SPSS version 19.0. This analysis began with checking the adequacy of the model by testing the normality of the parameter value distributions for all treatments using ShapiroWilk's test ( $p$-value $>0.05$ ), since there were less than 50 data points. Then two-way ANOVA at a $95 \%$ confidence interval $(a=0.05)$ was employed to test the differences between the mean values. Duncan's multiple range test was used to compare the means of the five levels of curing times $(2,7,14,21$, and 28 days) and the three levels of curing temperature $\left(40,60\right.$, and $\left.80^{\circ} \mathrm{C}\right)$.

\section{RESULTS AND DISCUSSION}

\section{Characterization of starting materials}

Fig. 1 shows the XRD pattern of the synthesized HAp powder. It was found from the figure that the major component of powder was HAp with a small amount of $\beta$-TCP in a crystalline phase. A similar behaviour was observed for HAp produced via a mechanochemical reaction ${ }^{22-24}$. Chemical composition of CK showed that it was composed mainly of $59 \% \mathrm{SiO}_{2}, 36.71 \% \mathrm{Al}_{2} \mathrm{O}_{3} 1.43 \% \mathrm{TiO}_{2}, 1 \%$ $\mathrm{Fe}_{2} \mathrm{O}, 0.25 \% \mathrm{CaO} 0.07 \% \mathrm{MgO}$ and $0.03 \% \mathrm{SO}_{3}$. 


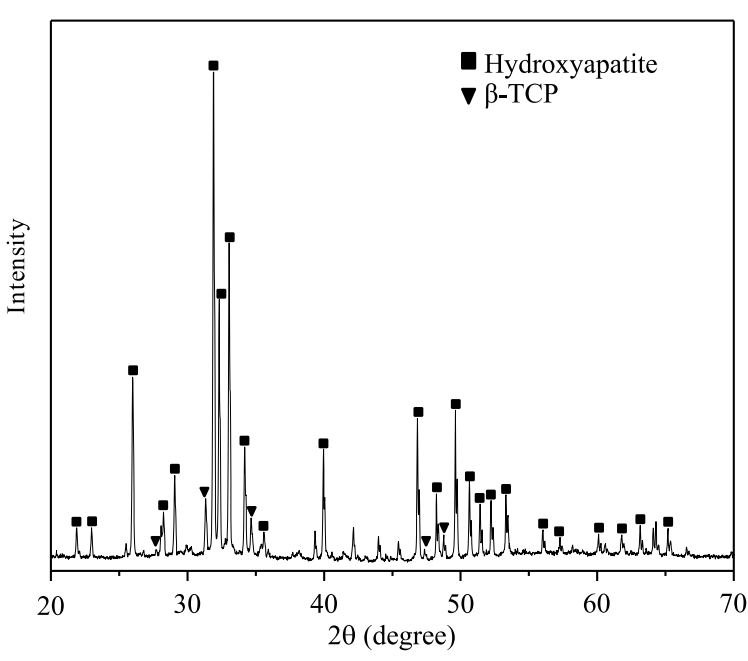

Fig. 1 XRD pattern of the hydroxyapatite synthesized from golden apple snail shell.

\section{Compressive strength}

The average compressive strengths of samples cured at 40,60 , and $80^{\circ} \mathrm{C}$ with various curing times are shown in Fig. 2. These three different curing temperatures were selected from observations of kaolin-based geopolymers, indicating that heat is beneficial for strength development and curing at temperatures below $100^{\circ} \mathrm{C}$ and that it has a significant contribution to the geopolymeric reaction in kaolin ${ }^{25}$. The curing times of $2,7,14,21$, and 28 days were selected to allow sufficient time for the geopolymerization process. From Fig. 2, it can be seen that the strength of the samples increased with increasing curing time at all temperatures. The strength linearly increased with increasing curing time for the samples cured at $40^{\circ} \mathrm{C}$ whereas the strength of samples cured at 60 and $80^{\circ} \mathrm{C}$ increased slightly over 7 days of curing. The highest strength, 37.8 $\mathrm{MPa}$, was observed from samples cured at $80^{\circ} \mathrm{C}$ for 28 days, while the compressive strength of cancellous bone is $2-45 \mathrm{MPa}^{14,15}$. From these results, it can be concluded that the appropriate curing conditions are a temperature of $80^{\circ} \mathrm{C}$ for at least 7 days for strong development of HAp/CK 25. This range of strength is potential for cancellous bone graft substitute. Statistical analyses were used to elucidate the influence of curing time and temperature on the strength of HAp/CK 25 samples.

\section{Statistical analysis}

The compressive strength of HAp/CK 25 was investigated using 15 treatments; five levels of curing

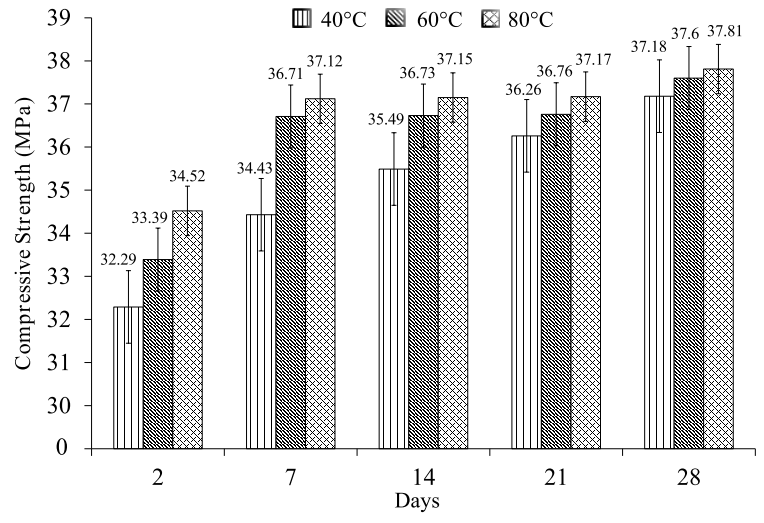

Fig. 2 Average compressive strengths of HAp/CK 25 samples after curing at 40,60 , and $80^{\circ} \mathrm{C}$ for various curing periods

Table 1 Statistical data and Shapiro-Wilk's test of compressive strength of HAp:CK 25 using 15 treatments to test for normality.

\begin{tabular}{lcccc}
\hline & Day_Temp & \multicolumn{3}{c}{ Shapiro-Wilk } \\
\cline { 3 - 5 } & & Statistic & df & Sig. \\
\hline Strength & 2_40 & 0.952 & 3 & 0.578 \\
& 2_60 & 1.000 & 3 & 1.000 \\
2_80 & 0.996 & 3 & 0.873 \\
7_40 & 0.980 & 3 & 0.729 \\
7_60 & 0.864 & 3 & 0.278 \\
7_80 & 0.864 & 3 & 0.278 \\
14_40 & 0.797 & 3 & 0.108 \\
14_60 & 0.999 & 3 & 0.935 \\
& 14_80 & 0.970 & 3 & 0.670 \\
21_40 & 0.945 & 3 & 0.549 \\
21_60 & 0.967 & 3 & 0.654 \\
21_80 & 0.827 & 3 & 0.181 \\
28_40 & 0.947 & 3 & 0.558 \\
28_60 & 0.999 & 3 & 0.956 \\
28_80 & 0.935 & 3 & 0.506 \\
\hline
\end{tabular}

time and three levels of curing temperature. Three replicates were made for each treatment and they were analysed statistically. The model adequacy was investigated using Shapiro-Wilk's test to verify data normality. The results show that the compressive strength data of HAp/CK 25 was normally distributed ( $p$-value $>0.05$ ) (Table 1$)$. The results indicated that these data were adequate for further statistical analysis, assuming a normal distribution.

A two-way ANOVA at a 95\% confidence interval was employed to investigate the effects of curing temperature and time on the compressive strength of HAp/CK 25. The factors were considered sep- 
Table 2 Two-way ANOVA test of the effects of curing temperature and time on the compressive strength of HAp/CK 25. Tests factor: interaction effects; dependent variable: strength

\begin{tabular}{lccccc}
\hline Source & Type III SS & df & Mean Square & F & Sig. \\
\hline $\mathrm{C}^{\dagger}$ Model & $114.9^{\mathrm{a}}$ & 14 & 8.2 & 6.3 & 0.0 \\
Intercept & 58459.5 & 1 & 58459.5 & 45124.2 & 0.0 \\
Day & 88.6 & 4 & 22.2 & 17.1 & 0.0 \\
temp & 20.6 & 2 & 10.3 & 8.0 & 0.0 \\
Day Temp & 5.7 & 8 & 0.7 & 0.6 & 0.8 \\
Error & 38.9 & 30 & 1.3 & & \\
Total & 58613.3 & 45 & & & \\
$\mathrm{C}^{\dagger}$ Total & 153.8 & 44 \\
\hline${ }^{a} \mathrm{R}^{2}=0.747$ (Adjusted $\left.\mathrm{R}^{2}=0.629\right)$. Type III SS $=$ Type \\
\multicolumn{1}{l}{ III sum of squares. $\mathrm{C}^{\dagger}=$ corrected. }
\end{tabular}

arately and in aggregate. The results are shown in Table 2. The ANOVA results revealed that both curing time and curing temperature significantly affected ( $p$-value $<0.05$ ) the compressive strength of HAp/CK 25, while the interaction between curing time and curing temperature showed no significant effect ( $p$-value $>0.05$ ) on the compressive strength of HAp/CK 25, (Table 2).

Furthermore, the Pearson correlation coefficient (Table 3) showed that the effects of curing time and temperature on compressive strength are related in a positive linear sense. The correlation value between curing time and compressive strength was 0.660 and between curing temperature and compressive strength was 0.359 . This means the compressive strength of HAp/CK 25 increased with increasing curing time. Also, at a higher curing temperature, the compressive strength was greater than at a lower curing temperature. Furthermore, it was found that the correlation between curing time and compressive strength was much stronger than that between curing temperature and compressive strength $(0.660>0.359)$ as shown in Table 3. Many studies on geopolymers conformed that curing temperature and curing time significantly influence the compressive strength ${ }^{19,20,26,27}$.

Duncan's multiple range test was then used to compare the range of a subset of the compressive strengths of HAp/CK 25 based on curing time and another range of a subset of the compressive strengths of HAp/CK 25 based on curing temperature. The results are shown in Table 4.

The compressive strength of HAp/CK 25 increased significantly with increased curing time. However, there were no significant differences in
Table 3 Pearson correlation of curing time and curing temperature with the compressive strength of HAp/CK 25.

\begin{tabular}{lcccc}
\hline & & Day & Temp & Strength \\
\hline Day & Pearson correlation & 1 & 0.000 & 0.660 \\
& Sig. (2-tailed) & & 1.000 & 0.000 \\
& $\mathrm{~N}$ & 45 & 45 & 45 \\
Temp & Pearson correlation & 0.000 & 1 & 0.359 \\
& Sig. (2-tailed) & 1.000 & & 0.016 \\
\multirow{4}{*}{ Strength } & N & 45 & 45 & 45 \\
& Pearson correlation & 0.660 & 0.359 & 1 \\
& Sig. (2-tailed) & 0.000 & 0.016 & \\
& N & 45 & 45 & 45 \\
\hline
\end{tabular}

Table 4 Duncan's multiple range test of curing temperature and curing time on the compressive strength of HAp/CK 25.

\begin{tabular}{lcccccccc}
\hline $\mathrm{C}^{\dagger}$ time & $\mathrm{N}$ & \multicolumn{3}{c}{ Subset } & & $\mathrm{C}^{\dagger}$ temp. & $\mathrm{N}$ & \multicolumn{2}{c}{ Subset } \\
\cline { 3 - 5 } & & 1 & 2 & 3 & & & 1 & 2 \\
\hline 2.00 & 9 & 33.4 & & & 40.0 & 15 & 35.1 & \\
7.00 & 9 & & 36.1 & & 60.0 & 15 & & 36.2 \\
14.0 & 9 & & 36.5 & 36.5 & 80.0 & 15 & & 36.8 \\
21.0 & 9 & & 36.7 & 36.7 & Sig. & & 1.0 & 0.2 \\
28.0 & 9 & & & 37.5 & & & & \\
Sig. & & 1.0 & 0.3 & 0.1 & & & & \\
\hline
\end{tabular}

$\mathrm{N}=$ Sample size, Sig. $=$ Significance. $\mathrm{C}^{\dagger}=$ cured.

the compressive strengths of HAp/CK 25 after 7, 14, and 21 days of curing at a $95 \%$ confidence interval. The highest compressive strength, $36.7 \mathrm{MPa}$, was observed after 21 days. Furthermore, after 14, 21, and 28 days of curing, there were no significant differences in the compressive strengths of HAp/CK 25 at a $95 \%$ confidence interval. The highest compressive strength, $37.5 \mathrm{MPa}$, was after 28 days.

The compressive strength of HAp/CK 25 increased significantly with increased curing temperature. There were significant differences in compressive strength of HAp/CK 25 with curing at $40^{\circ} \mathrm{C}$ among all pairs of curing temperatures at a 95\% confidence interval. However, there were no significant differences in compressive strength of HAp/CK 25 with curing at $60^{\circ} \mathrm{C}$ and $80^{\circ} \mathrm{C}$ with a $95 \%$ confidence interval. The highest compressive strength, $36.8 \mathrm{MPa}$, was observed after curing at $80^{\circ} \mathrm{C}$. From these results, it can be concluded that curing at $60^{\circ} \mathrm{C}$ for 14 days represents the optimal curing conditions to achieve the maximal compressive strength of HAp/CK 25. Future research is required to evaluate the bioactivity and other mechanical and physical properties, such as bending 
strength, porosity, surface morphology of HAp/CK 25 under optimal curing condition.

\section{CONCLUSIONS}

The effects of curing time $(2,7,14,21$, and 28 days) and temperature $\left(40^{\circ} \mathrm{C}, 60^{\circ} \mathrm{C}\right.$ and $\left.80^{\circ} \mathrm{C}\right)$ of hydroxyapatite combined with calcined kaolin (1:3 mass ratio) were investigated. Statistical analyses were used to determine the level of influence of each factor. The conclusions of the current study are as follows.

(1) The compressive strength of the HAp/CK 25 increased significantly with increasing curing temperature and curing time.

(2) The highest compressive strength of HAp/CK $25,37.8 \mathrm{MPa}$, was achieved after curing the sample at $80{ }^{\circ} \mathrm{C}$ for 28 days.

(3) Statistical analyses revealed that both curing temperature and curing time significantly affected compressive strength, while there were no interactions between these two factors.

(4) The optimal curing conditions for HAp/CK 25 to achieve its highest compressive strength was $60^{\circ} \mathrm{C}$ for 14 days.

(5) The combinations between HAp/CK 25 provided suitably high compressive strength for the bone substitute material.

Acknowledgements: This study was supported by the Capacity Building Program for New Researcher 2018 from National Research Council of Thailand (NRCT). The third author would like to acknowledge the support of Thailand Research Fund (TRF) under the TRF Distinguished Research Professor Grant No. DPG6180002. The last author would like to acknowledge the support of the Thailand Research Fund and the Office of the Higher Education Commission Grant No. MRG6180026 and the Farm Engineering and Automatic Control Technology Research Group (FEAT), Khon Kaen University, Thailand.

\section{REFERENCES}

1. Wang W, Yeung K WK (2017) Bone grafts and biomaterials substitutes for bone defect repair: A review. Bioact Mater 4, 224-47.

2. Benmarouane A, Hansen T, Lodini A (2004) Heat treatment of bovine bone preceding spatially resolved texture investigation by neutron diffraction. Physica B 350, 1-3.

3. Arahira T, Maruta M, Matsuya S, Todo M (2015) Development and characterization of a novel porous $\beta$-TCP scaffold with a three-dimensional PLLA network structure for use in bone tissue engineering. Mater Lett 152, 148-50.
4. Chen Q, Roether JA, Boccaccini AR (2008) Tissue engineering scaffolds from bioactive glass and composite materials. Tissue Eng 4, 1-27.

5. Hassaan MM, Khater HM, El-Mahllawy M S, El Nagar AM (2015) Production of geopolymer composites enhanced by nano-kaolin material. $J$ Adv Ceram 4, 245-52.

6. Catauro M, Bollino F, Papale F, Lamanna G (2014) Investigation of the sample preparation and curing treatment effects on mechanical properties and bioactivity of silica rich metakaolin geopolymer. Mater Sci Eng: C 36, 20-4.

7. Pangdaeng S, Sata V, Aguiar J B, Pacheco-Torgal F, Chindaprasirt P (2015) Apatite formation on calcined kaolin-white Portland cement geopolymer. Mater Sci Eng: C 51, 1-6.

8. MacKenzie KJ, Rahner N (2010) Calcium-containing inorganic polymers as potential bioactive materials. J Mater Sci 45, 999-1007.

9. Oudadesse H, Derrien AC, Martin S, Chaair H, Cathelineau G (2008) Surface and interface investigation of aluminosilicate biomaterial by the 'in vivo' experiments. Appl Surf Sci 255, 593-6.

10. Davidovits J (1999) Chemistry of Geopolymeric Systems. Terminology In Proceedings of 99 International Conference, France, pp 9.

11. Van Jaarsveld JG, Van Deventer JS, Lukey GC (2003) The characterization of source materials in fly ashbased geopolymers. Mater Lett 57, 1272-80.

12. Swanepoel JC, Strydom CA (2002) Utilization of fly ash in a geopolymeric material. Appl Geochem 17, 1143-8.

13. RovnanÃ $\tilde{O}^{\mathrm{k}} \mathrm{P}$ (2010) Effect of curing temperature on the development of hard structure of metakaolinbased geopolymer. Constr Build Mater 24, 1176-83.

14. Hannink G, Arts JC (2011) Bioresorbability, porosity and mechanical strength of bone substitutes: what is optimal for bone regeneration? Injury 42, 22-5.

15. Sopyan I, Mel M, Ramesh S, Khalid KA (2007) Porous hydroxyapatite for artificial bone applications. Sci Technol Adv Mater 8, 116-23.

16. Sutthi R, Pangdaeng S, Chindaprasirt P, Otsuka Y, Mutoh Y, Laonapakul T (2017) Hydroxyapatite from golden apple snail shell with calcined kaolin for biomaterial applications. Key Eng Mater 718, 133-8.

17. Leelatawonchai P, Laonapakul T (2014) Preparation and characterization of calcium sources from golden apple snail shell for naturally based biomaterials. Adv Mater Res 931, 370-4.

18. Chindaprasirt P, Jaturapitakkul C, Chalee W, Rattanasak U (2009) Comparative study on the characteristics of fly ash and bottom ash geopolymers. Waste Manage 29, 539-43.

19. Khale D, Chaudhary R (2007) Mechanism of geopolymerization and factors influencing its development: a review. J Mater Sci 42, 729-46.

20. Mo BH, Zhu H, Cui XM, He Y, Gong SY (2014) 
Effect of curing temperature on geopolymerization of metakaolin-based geopolymers. Appl Clay Sci 99, 144-8.

21. ASTM C109 (2005) Standard test method of compressive strength of hydraulic cement mortars (using 2-in. [or $50 \mathrm{~mm}$ ] cube specimens) Annual Book of ASTM Standard pp 76-81.

22. Suchanek WL, Shuk P, Byrappa K, Riman RE, TenHuisen KS, Janas VF (2002) Mechanochemicalhydrothermal synthesis of carbonated apatite powders at room temperature. Biomaterials 23, 699-710.

23. Yeong K CB, Wang J, Ng SS (2001) Mechanochemical synthesis of nanocrystalline hydroxyapatite from $\mathrm{CaO}$ and $\mathrm{CaHPO}_{4}$. Biomaterials 22, 2705-12.

24. Rhee SH (2002) Synthesis of hydroxyapatite via mechanochemical treatment. Biomaterials 23, 114752.

25. Heah CY, Kamarudin H, Al Bakri AM, Binhussain M, Luqman M, Nizar I K, et al (2011) Effect of Curing Profile on Kaolin-based Geopolymers. Physics Procedia 22, 305-11.

26. Mishra A, Choudhary D, Jain N, Kumar M, Sharda N, Dutt D (2008) Effect of concentration of alkaline liquid and curing time on strength and water absorption of geopolymer concrete. ARPN Journal of engineering and Applied Sciences 3, 14-8.

27. Torkittikul P, Chaipanich A (2009) Investigation of the mechanical and in vitro biological properties of ordinary and white Portland cements. ScienceAsia 35, 358-64. 